\title{
Sustainability Analysis for Gayo Coffee Supply Chain
}

\author{
Rachman Jaya \#, Machfud *, Sapta Raharja *, Marimin ${ }^{*}$ \\ ${ }^{\#}$ Assessment Institute for Agricultural Technology of Aceh, Banda Aceh,23125, Indonesia \\ E-mail:abah_pipah@yahoo.co.id \\ * Agroindustrial Technology Department, Bogor Agricultural University, Bogor, 16002,Indonesia \\ E-mail: Machfud_yasrin@yahoo.com; saptaraharja@ipb.ac.id; Marimin_07@yahoo.com
}

\begin{abstract}
Sustainable supply chain is a development of the conventional supply chains that discuses trade-off among economic, social and environmental dimensions in order to achieve better responsiveness in terms of quality, quantity and time-delivery in the supply chain structure. The objective of this research was to determine the Gayo coffee supply chain sustainability. The research was conducted at Bener Meriah and Aceh Tengah Districts, Aceh Province, Indonesia. Key actors in the supply chain considered were farmers, collectors, agro-industry and exporter. Sustainability dimensions considered in this research were the economic, social, environmental and material resources. The performance of each aspect was analyzed by using Multi-dimensional scaling and leverage analysis. The result of the research showed that the composite of Gayo coffee supply chain sustainability index was 33.53 which mean less sustainable level. Therefore it is recommended to reengineering the Gayo coffee supply chain by considering all of the four sustainability dimensions above.
\end{abstract}

Keywords - Sustainability Analysis, Supply Chain, Gayo Coffee.

\section{INTRODUCTION}

\section{A. Background}

Sustainable supply chain (SSC) is a development of the conventional supply chain where trade-off between economic, social and environmental dimensions is considered to be an important aspect ([1], [2], [3]). It is mostly focus on fulfilling quality, quantity and time-delivery for responsiveness to serve their customers. In addition to three dimensions, SSC also discusses technology and material resources aspects. Base on coffee commodity, [4]; [5] stated that these aspects very important to reach. SSM due to complexity of the problem are very high because covered trade-off all dimension. Particularly, that expose of agri-supply chain, many research have been assessing about this topic i.e. sugars [6], vegetables [7], whereas that centers on coffee like [8], who has modeled procurement process in coffee supply chain at India, [9] also has determined core aspects for reaching sustainable agro industry through utilization of by products and added-value.

Gayo highland is situated in the Aceh Province around Bukit Barisan Mountains in Indonesia. In local government structure, these locations there are three districts such as Bener Meriah, Aceh Tengah and Gayo Lues. It is located on 850-1500 meters above sea level, therefore suitable for the cultivation of Arabica coffee. Arabica coffee is a popular export commodity to several countries like USA, Japan and Europe union. Although total value of export Gayo coffee reached US\$17 in 2010, 130\% increase compared 2009, the average price achieved was IDR 54.000 per $\mathrm{kg}$ (ready to export). A decrease of about $10 \%$ occurred due to the declined of world coffee price mainly in the USA and Euro market as the largest consumer of the commodity ([3],[10]). Amid weak of world coffee price, actually the farmers haven't felt benefit of Gayo Coffee business, such as premium price for implementation fair-trade, rain-forest, organic as well as geographic indication certifications (ID G 000000005). These problems are caused by unfair trade by exporter level and buyers in importer countries ([11];[12]), so sustainable supply chain Gayo Coffee is very hard to realization ([13],[14]).

Base on the fact, in another word that supply chain structure of Gayo Coffee hasn't shown sustainability, in other words, the sense for each dimension doesn't have inter-relation. This research addresses the inter-relation between the four dimensions in order to achieve sustainable supply chain of Gayo Coffee.

\section{B. Objective}

The objective of this research was to determine the Gayo coffee supply chain sustainability and then to formulate recommendation for improving the sustainability. 


\section{RESEARCH METHODOLOGY}

\section{A. Logical Framework}

The fundamental of this research was inter-relational in Gayo coffee supply chain which including the economic, social, environmental and material resources aspects. Based on the information described previously, a gap existed in the integrations among aspects has not been running to reach sustainable supply chain. Detail logical framework can be seen at Fig. 1.

Base on Fig. 2 can be explained that, our activities began on review about structure of Gayo coffee business structure, a core this activity is determining of tier of Gayo coffee supply chain. The aim of sustainable analysis is to find out existing state of the sustainability of Gayo coffee supply chain. Technique used is multi-dimensional scaling and leverage analysis, that application namely rap-coffee, it is adopted by rap-fish ([14], [15], [16]).

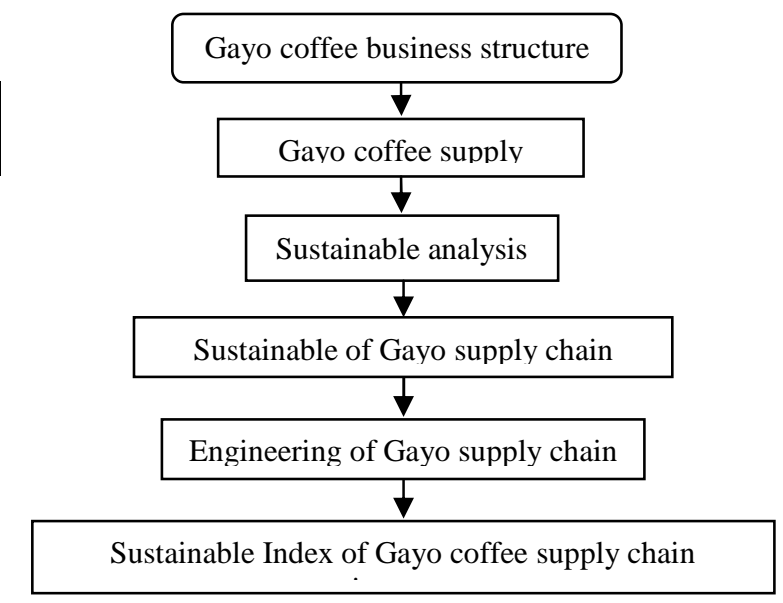

Fig 1. Logical Framework Research

\section{B. Research Design}

Design of this research is to refer system approach [17]. The stages of this research design have to through that systematic, logic and structured: i) preliminary study; 2) design sustainable system; 3) sustainable modeling; 4) development of alternative policy scenario. Detail of research design can be seen at Fig. 2.

\section{Data Collection}

Primary and secondary data were collected from reports of National Statistic Board (Badan Pusat Statistik) and local government agencies as well as by in-depth interviews with some experts. Experts were determined based on these factors: 1. Their reputation and competencies should be appropriate with topic of study, 2. Have experiences in coffee industry at least 15 years, 3 . Agree for deep interview. Experts were: Researcher, lectures and players in Gayo coffee industry.

\section{RESULT AND DISCUSSION}

The system analysis was done by conducting requirement analysis on components associated with the sustainability of Gayo supply chain. The result of this stage was known dimensions related with the core of the research. Based on expert judgment, four dimensions were revealed, i.e. economic, social, environmental and material resources. ([4],[13] as well as [14]), stated that the fourth dimension is the main pillar in sustainability of an agro industry. One of the most important forms in this case was the integration of all dimensions to reach consensus for each actor [1]. Dimensions and attributes in SSCM of Gayo Coffee can be seen at Table 1.

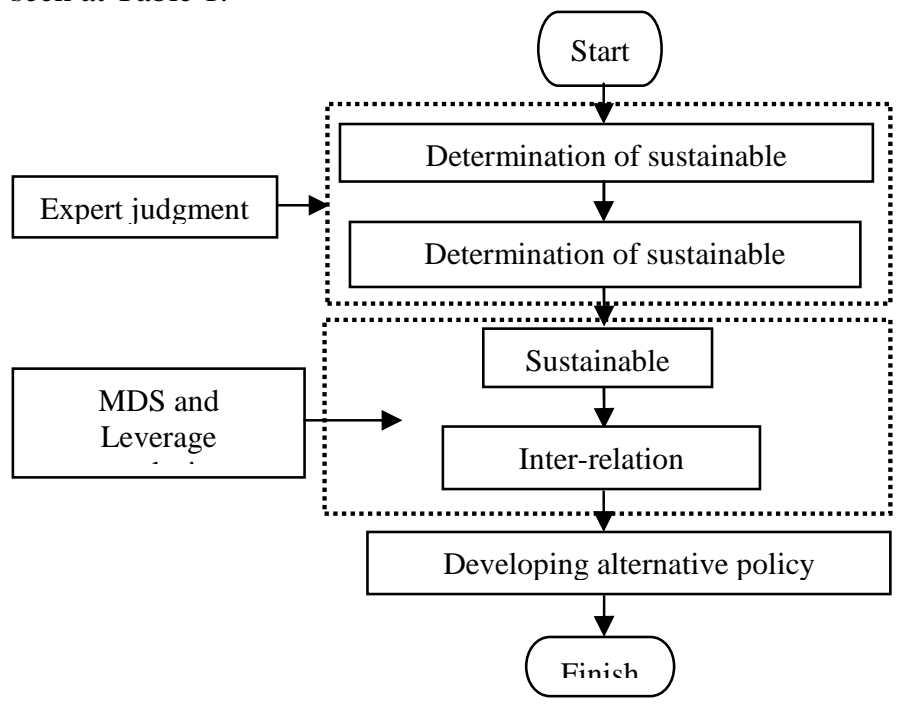

Fig 2. Research Design

TABLE I

DIMENSIONS AND ATTRIBUTES IN SSCM OF GAYO SUPPLY CHAIN

\begin{tabular}{lll}
\hline No. & Dimension & Attribute \\
\hline 1. & Economic & $\bullet$ Fair profit distribution \\
& $\bullet$ Profit margin \\
& $\bullet$ Net profit \\
& $\bullet$ Market accessibility \\
\hline 2. $\quad$ Social & $\bullet$ Fulfillment of safety and health care \\
& $\bullet$ Fulfillments fundamental right \\
& $\bullet$ Increasing of employee skill \\
& $\bullet$ Institution \\
\hline 3. & Environmental & $\bullet$ Water resource efficiency \\
& & $\bullet$ Organic agriculture \\
& & $\bullet$ Solid waste utilization \\
\hline 4. & Material resources & $\bullet$ Continuously of raw material \\
& & $\bullet$ Sufficiency of raw material \\
& & $\bullet$ Quality of raw material \\
& & $\bullet$ Carrying capacity \\
\hline
\end{tabular}

\section{B. Gayo Cofee Supply Chain Structure}


Arabica coffee produced at Gayo highland area is named as Gayo Coffee. It refers to a region located at Bukit Barisan highland and included in Aceh Province. The districts that produce Gayo coffee are Bener Meriah, Aceh Tengah and Gayo Lues, with Bener Meriah and Aceh Tengah being the dominant region. Gayo coffee production in 2010 amounted 35.000 tones; whereas extensive planting reached $81.000 \mathrm{Ha}$ and productivity achieved 0.79 ton/Ha [18]. The structure of Gayo coffee supply chain can be divided into two main components i.e. internal and external supply chain. Internal elements covered farmers, first collectors (village), second collectors (sub district), agro industry and exporter. Detail the Gayo coffee supply chain is presented in Fig 3.

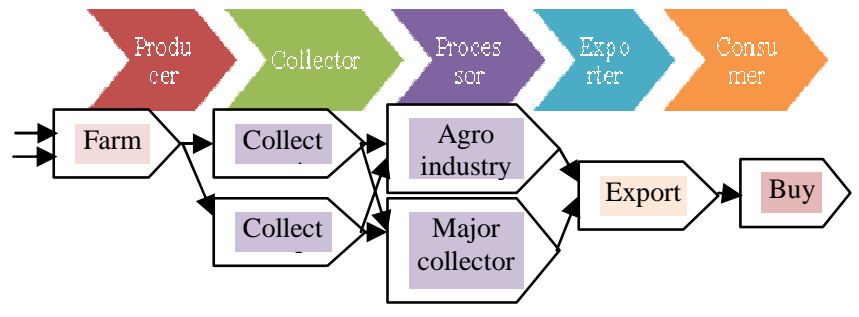

Fig 3. Gayo Cofee Supply Chain Structure

In 2010, the numbers of agro industry at Gayo highland are fifteen, however only five has been identified as exporter. In this research, basic problems on Gayo supply chain structure was identified, there is gap of benefit among each actors and quality specification have not been fulfilled [10]. The business activities in this area has existed in a long time, but until now it has not given better livelihood for farmers involved in the plantation, although several certifications have been implemented in this area, for instance geographic indication, rain-forest, fair-trade and organic it hasn't contributed significantly to the life of the farmers. This occurred due to the unfair trade normally conducted by the buyers ([11],[12]), so necessary a real effort to solve that problem, one of the way by fair benefit distribution according the scale business for each actors.

Sustainable Gayo Coffee Supply Chain Index

The result of the MDS analysis was 35.33 (less sustainable), therefore from this index it is argued that overall state of business Gayo coffee is less sustainable due to lack of understanding of the business process. Distribution profit was received more by the exporter rather than the farmers, even though the farmers have business risk more than exporter.

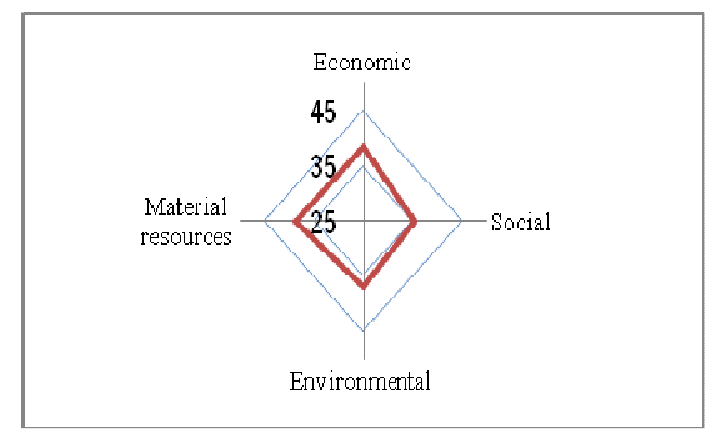

Fig. 4Kite Diagram of multi-dimensional sustainable Gayo coffee supply chain
Another variable considered to be very important was the fulfillment of quality characteristic. In term of social dimension, main players have not been achieved rights of the employees in health care (insurance) and occupational safety, hence environmental aspect showed when a batch processing water consumptions still high, in this case more $3-4 \mathrm{~m}^{3} /$ ton (Fig. 4).

\section{Economic Dimension}

Economic dimension is an urgent aspect in sustainability. The result of MDS analysis has shown that sustainability index was 38.44 (less sustainable), R2=0.93 and stress at around 0.18 . Sustainability index can be seen more detail in Fig. 5

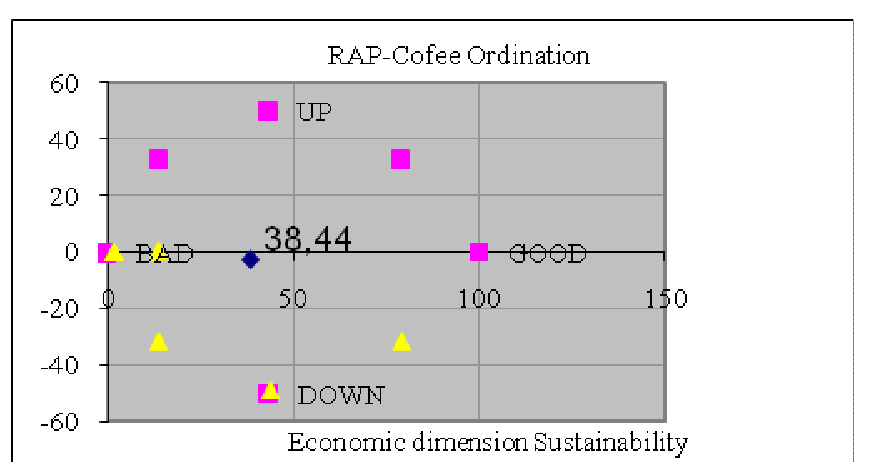

Fig 5. Sustainable index of economic dimension

A sustainable index for economic dimension level showed that a condition with less sustainable is ranged between 25 50. This situation leads to unfair sharing of profit distribution for each actor, whereas exporters benefit higher profit than farmers although they endure less risk. This is parallel with [19] that, in agri-supply chain, the farmers normally have take profit about $20-30 \%$ of totally profit margin, despite they suffer higher risk which can reach up to $80 \%$, therefore a new fair mechanism in profit sharing is needed in Gayo coffee supply chain. This condition similar with result of leverage analysis that can be observed at Fig. 6

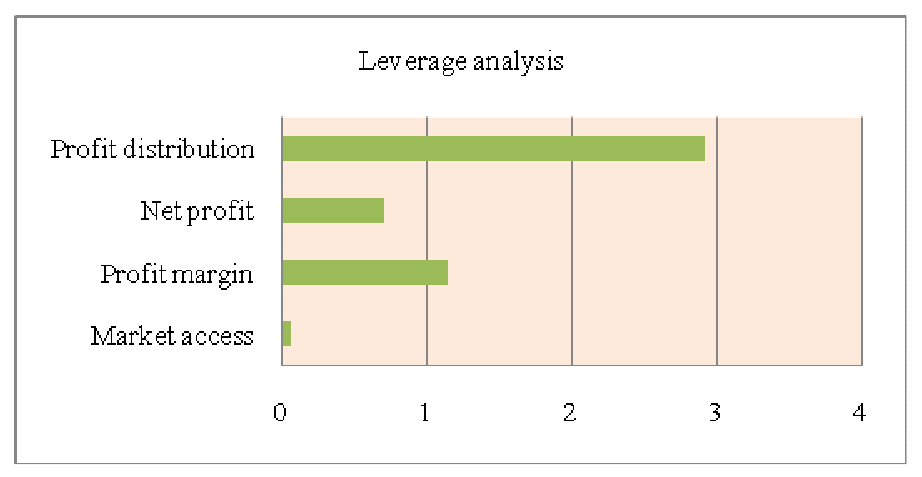

Fig 6. Leverage analysis of economic dimension

\section{Social Dimension}

Result of MDS analysis for social dimension index was 35.31 (less sustainable), stress index 0.181 and $R^{2}=0.94$. The calculation is presented in Fig 7. Fig 7 and 8 showed that the situation was less sustainable in this dimension, as 
shown by sustainable index. This aspect included several critical attributes such as safety compliance and health care for employees and people who live around business units. [5] emphasized that in order to achieve sustainable in coffee industry, two important aspects that have to be guaranteed by local government and agro-industry are safety and health care of the employees.

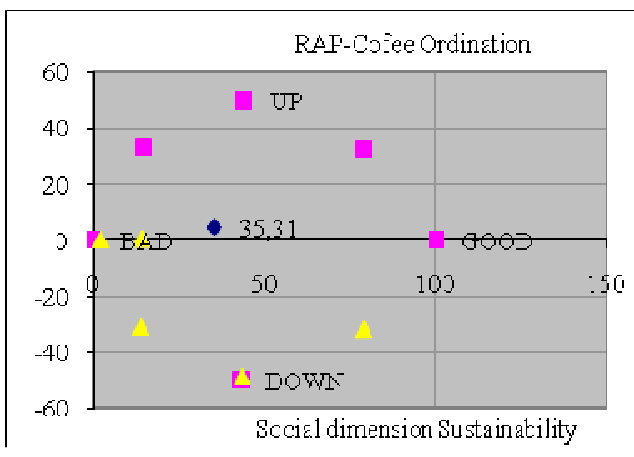

Fig 7. Sustainable Index of social dimension

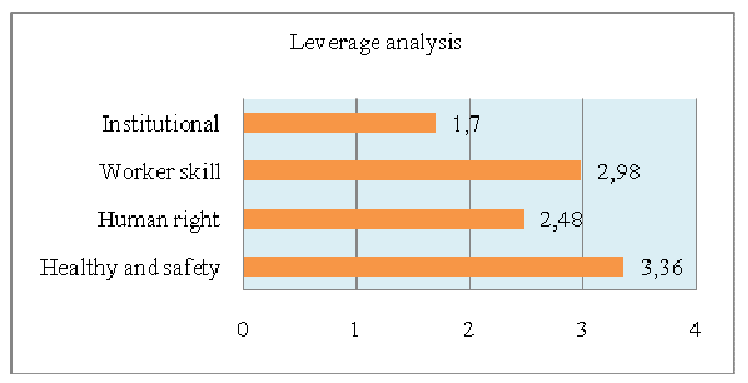

Fig 8. Leverage analysis of social dimension

\section{E. Environmental Dimension}

In this dimension, result of MDS analysis (rep-coffee) showed index of sustainability was 36.99 which mean less sustainable, with stress index was 0.183 and $\mathrm{R}^{2}=0.94$. The calculation can be seen in Fig 9 and 10. As shown in Fig 9, critical point in this aspect was level of water efficiency in processing is still high, compared to water consumption for other products such as pulp and skin. In this dilemma, [9] suggested that the actors in supply chain structure must be focused on these aspects. [14] stated that by-product (pulp and skin) has value, because it can be utilized to mushroom growth medium, citric acid, compos, ethanol, bio-active, and bio-gas.

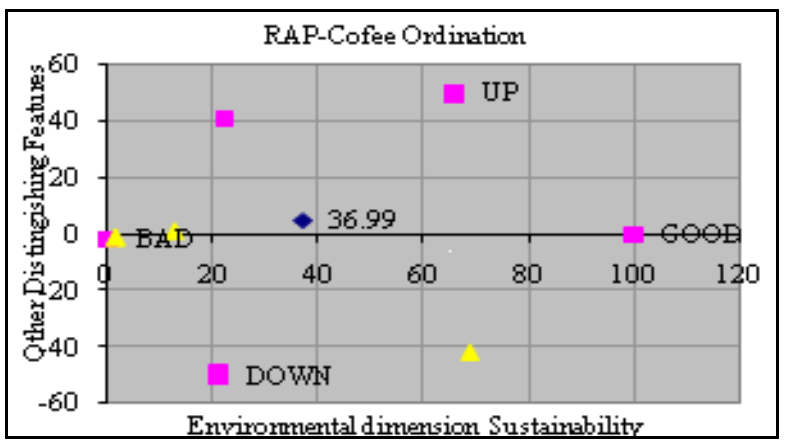

Fig 9. Sustainable Index of environmental dimension

\section{F. Material Resources Dimension}

In this dimension, we showed that sustainability index after MDS analysis using rap-coffee was 38.78 (less sustainable), whereas stress index was 0.183 and $R^{2}=0.94$ (see Fig. 11). Material resources include sufficiency and continuity (See Fig 12). Basic theory of supply chain explained that in order to satisfy consumers, all actors who are involved in the system have to focus on those mentioned aspects, beside quantity and time delivery of product.

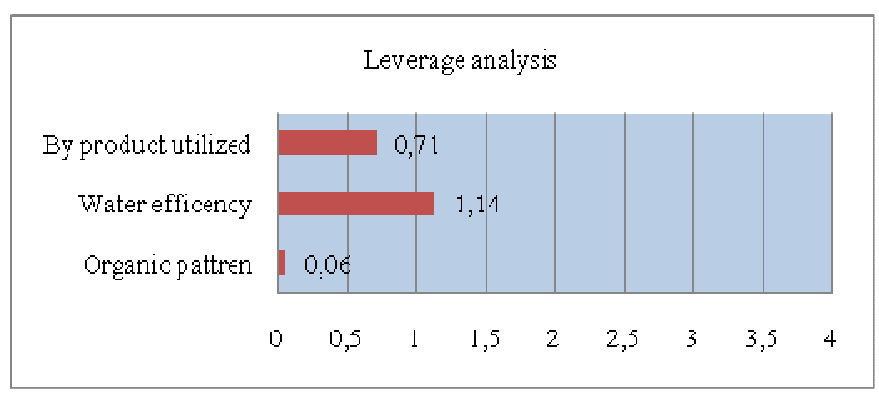

Fig 10. Leverage analysis of environmental dimension

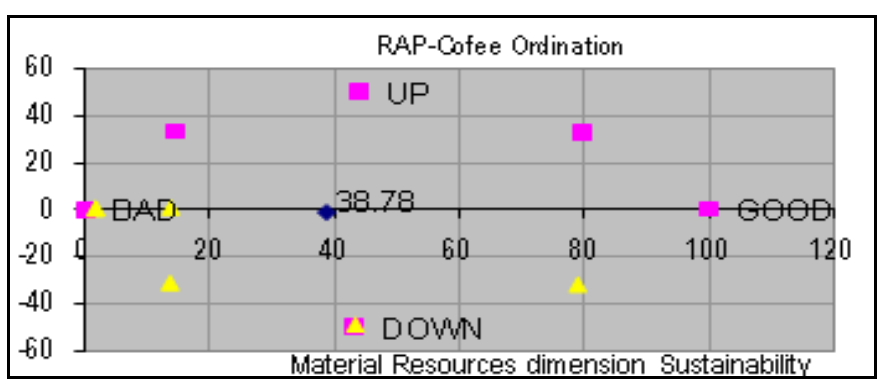

Fig 11. Sustainable Index of material resources dimension

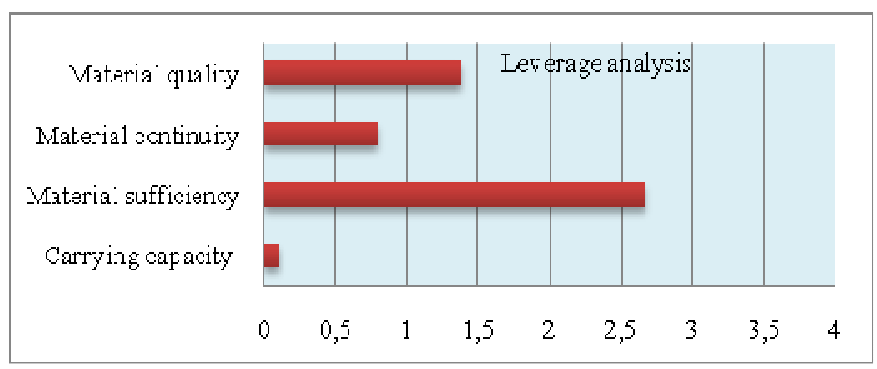

Fig 12. Leverage analysis of material resources dimension

\section{G. Inter-relation Analysis}

Inter-relation analysis is linkage among each dimension in Gayo coffee supply chain structure. The analysis was based on result of leverage analysis and causal-loop diagram was used as a tool (Fig. 13). As shown in the Figure, we observed that every dimension was linked each other. After deeper analysis, we found that fairness profit sharing among players was a major attribute in economic dimension, while fulfilling health care and safety work for employees was important in social dimension. Moreover, water-use efficiency and sufficiency of raw material were important in environment and material resources respectively. Therefore, stakeholders in Gayo coffee supply chain (i.e. local 


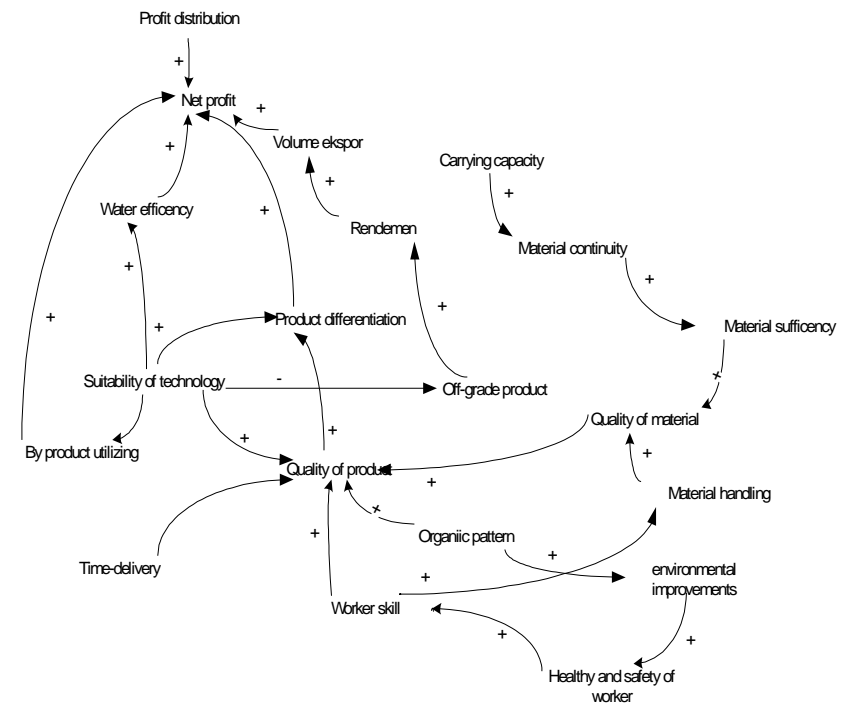

government and agro-industry) should create an alternative policy based on result of this study.

Fig 13 Causal loop diagram in Gayo coffee supply chain

\section{H. Recommendation}

This research recommends:

1) Agro industry: Should be fair in profit sharing based on contract in order to increase farmers income, should use labeled seed such as Gayo 1 and Gayo 2 to increase raw material sufficiency which then lead to increase productivity more than 0.79 ton/Ha, should apply wet rendering technology in order to decrease water consumption in coffee processing.

2) Local government: Provide an encouraging to agro industry for balanced profit distribution through regulation (collaborating with local parliament), moreover it can be mediator for negotiation to get tax holiday, and so can increasing profitability all tier in Gayo coffee supply chain.

\section{CONCLUSIONS AND RECOMMENDATION}

This research concluded that:

1. Sustainability Index of Gayo coffee supply chain was less sustainable (37.33), so needed to reengineering for improving the leverage of all attributes in each dimensions.

2. Economic dimension, index sustainable 38.44, social (35.31), environmental (36.99) and material resources (38.78). All categories showed less sustainable.

Policy recommendations for stakeholder (agro industry) are balanced profit distribution that realization by contract, introduction labeled seed like's Gayo 1 and 2, and applying wet rendering technology. Local government can be mediator for agro industry to get tax dispensation such as tax holiday.

\section{REFERENCES}

[1] R. Cuthbertson, The Need for Sustainable Supply Chain Management in Sustainable Supply Chain Management: Practical Ideas for Moving towards Best Practice. Springer-Verlag Berlin Heidelberg. 2001.

[2] S. Gupta and O.D Palsule-Desai, "Sustainable Supply Chain Management: Review and Research Opportunities," IIMB Management Review. Article in Press. 2011..

[3] S. Zailani, K. Jeyaraman, G. Vengadasan and R. Premkumar, "Sustainable Supply Chain Management (SSCM) in Malaysia: A Survey," Int. J. Production Economics, Article-inpress. 2012.

[4] B.H. Purnomo, "A Design of Sustainability Predictive Model for Capture Fishery Agroindustry," [Ph.D.Thesis]. Bogor Agricultural University, Bogor, Indonesia. 2012.

[5] D.Giovannucci and J. Potts, Seeking Sustainability: COSA Preliminary Analysis of Sustainability Initiatives in the Coffee Sector. Winnipeg, Canada: Committee on Sustainability Assessment. 2008.

[6] P.Y.LGal, P.W.L Lyne, E. Meyer, and L.G Soler, "Impact of Sugarcane Supply Scheduling on Mill Sugar Production: A South African Study Case," Agricultural System, vol 96, pp. 64-74. 2008.

[7] R. Stringer, N. Sang, and A. Croppenstedt, "Producers, Processor and Procurement Decision: The Case of Vegetable Supply Chain in China," World Development, vol 37 (11), pp, 1773-1780. 2008.

[8] R.D. Banker, and S. Mitra, "Procurement Models in the Agricultural Supply Chain: a Case Study of Online Coffee Auctions in India," Electronic Commerce Research and Applications, vol,6 (3,)pp, 309-321.2007.

[9] P.S. Murthy, and M.M Naidu, "Sustainable Management of Coffee Industry by-products and Value Addition [A review], "Resources, Conservation and Recycling," vol, 66, pp, 45- 58. 2012.

[10] R. Jaya, Machfud, and M. Ismail, "Applications of ISM and MEMCDM Technique for Identification Stakeholder Position and Alternatives Activity for Improving Quality of Gayo Coffee," J. Teknologi Industri Pertanian, Vol 21 (1),pp,1-8. 2011.

[11] S. Ponte, "The Latte Revolution? Regulation, Market and Consumption in Global Coffee Chain," World Development, vol 30, pp,1099-1122. 2002.

[12] L.T. Raynolds, "Mainstream Fair Trade Coffee: From Partnership to Traceability," World Development, vol 37(6),pp, 1083-1093. 2009.

[13] M. Adams and A.E Ghaly, "Maximizing Sustainability of The Costa Rican Coffee Industry," J. of Cleaner Production, vol 15,pp, 17161729. 2007.

[14] E. Novita, "Processing Design at Robusta Coffee Agroindustry Using Modified Wet Process Technology Based on Cleaner Production," [Ph.D thesis]. Bogor Agricultural University, Bogor, Indonesia. 2012.

[15] T.J. Pitcher, and P. Preikshot, "RAPFISH: a Rapid Appraisal Technique to Evaluate the Sustainability Status of Fisheries," Fisheries Research, vol 49, pp, 255-270. 2001.

[16] M.S Allahyari, "Fisheries Sustainability Assessment in Guilan Province, Iran. Journal of Food, Agriculture \& Environment, vol 8(3), pp, 1300-1304. 2010.

[17] G.S Parnell, P.J. Driscoll, and D.L. Henderson, Decision Making In Systems Engineering and Management. John Wiley \& Sons, Inc.USA. 2011.

[18] BPS Provinsi Aceh, Statistik Perkebunan Provinsi Aceh, Banda Aceh. 2010.

[19] Suharjito and Marimin, "Risks Balancing Model Of Agri-Supply Chain Using Fuzzy Risks Utility Regression," J. of Theoretical and Applied Information Technology, vol, 41(2), pp,13-23. 2012. 